\title{
THE SMALL CLAIMS COURT IN CANADA: SOME REFLECTIONS ON RECENT REFORMS*
}

\author{
WILLIAM A.W. NEILSON**
}

\begin{abstract}
The last ten years have been an extraordinary period with respect to legislation in the area of small claims dispute resolution. The author outlines how various provinces have reformed and experimented with their small claims courts to better suit the needs of the consumer. The costs and benefits of these reforms are analyzed with the competing values of diversity and uniformity in mind. The author examines the social policy behind these issues from several perspectives, including that of the potential litigant. judge and taxpayer.
\end{abstract}

\section{INTRODUCTION}

In this brief paper, I propose to raise a few questions about the diversity and direction of recent legislative reforms affecting the jurisdiction and operation of provincial small claims courts. My aims are limited and modest.

For more than a decade the principal criteria for the reform of the small claims system have been readily accepted in legal and consumer circles: accessibility, fairness, informality, timeliness and minimum costs. ' These common measuring rods have yielded, however, little uniformity or standardization in the various provincial small claims statutes that have emerged. Since recent developments ${ }^{2}$ suggest that this pattern in custom-made legislation will continue, it may be timely to take stock of the present situation. Are litigants, actual and potential, well served by our small claims courts? In this connection, the issues of monetary jurisdiction, evidence and costs will be addressed. Each topic illustrates the diversity of institutional reform practised by the provinces.

The reforms of the 1970's, it would appear, have yielded very mixed results. Timely, accessible, affordable justice for small claims remains an elusive goal in our civil courts system. Too often the fundamental issues of access and timeliness are determined by the accident of provincial residence or the absence of pretrial counselling services. It is questionable whether the present hodgepodge of court statutes represents an adequate response to the long identified needs of law reform in the provision of small claims justice.

Directions for improvement are explored in the concluding section of the paper. In particular, it is suggested that the pressures of economic recession and restraints in public sector spending provide an opportunity to reconsider the pace and direction of small claims law reform. Better

* This article is a revised version of an address by the author which was originally presented at a national conference entitled "The Small Claims and Access to Justice" which was sponsored by the Canadian Institute for the Administration of Justice and held in Vancouver, B.C. from January 27-30, 1982. Two other articles from this conference appeared in (1982) 20 Alta. L. Rev.

** Professor, Faculty of Law, University of Victoria.

1. See G. Adams, "The Small Claims Court and the Adversary Process: More Problems of Function and Form" (1973) 51 Can. Bar Rev. 583; Consumer Council, Justice out of Reach: A Case for Small Claims Courts (1970). For a more radical view, see T. Ison, "Small Claims" (1972) 35 Mod. L. Rev. 18.

2. The Small Claims Act, S.N. 1979, c. 34, proclaimed November 3, 1980; Small Claims Court Act, S.N.S. 1980, c. 16, proclaimed January 1, 1981. 
court and non-court systems can be fashioned if we are sensitive to lessons learned from changes attempted in the 1970's. The vigour and variety of recent efforts ought now to be succeeded by an interprovincial progress report which will evaluate the small claims system on the basis of commonly accepted criteria. The results will be found wanting and the basis for 'second generation' changes will be laid through this nation-wide exercise.

\section{THE IMPACT OF CONSUMER LAW DEVELOPMENTS}

It is fair to say that the reform of small claims legislation and procedures in the 1970's was part and parcel of the significant changes in consumer law at the federal and provincial levels of government. ${ }^{3}$ Without the rise of consumerism and its consequences for legislative change and public programs in consumer education, it is doubtful this topic would have its present significance.

As a primary forum for the resolution of consumer grievances, small claims courts have been the subject of careful and critical scrutiny by commentators here and elsewhere. ${ }^{4}$ Their procedures, accessibility and effectiveness have been examined and usually found to be wanting from the vantage point of unadvised consumer litigants. ${ }^{5}$ Saddled with antiquated statutes and minimal resources, the small claims system attracted little official priority in the early years of consumer law reform.

While law textbooks still referred blithely to freedom of contract, the parol evidence rule and the 'never-never' land of privity of contract, the full advent of a mass merchandising, credit-oriented marketing system was increasingly revealing the limitations of existing laws governing terms of purchase, safety requirements, sales representations and appropriate means of redress. ${ }^{6}$

In time, political markets responded to market realities and by the late 1960's, the newly established federal Department of Consumer and Corporate Affairs was sponsoring significant legislative initiatives in product safety requirements, packaging and textile labelling regulations, weights and measures, consumer notes and misleading advertising controls. By the early 1970's, provincial legislatures were enacting measures dealing with personal information reporting systems, warranties and guarantees, contract and credit disclosure requirements, and special forms of protection for the purchasers of everything from encyclopedias and cars to vacation packages.

The level of statutory activity is reflected in recent statistics released by the Economic Council of Canada in connection with its report on

3. For a discussion of this topic in greater detail, see W. Neilson, "The Future of Canadian Consumerism: A.Retrospective and Prospective View" in Proceedings of the 10th Annual Workshop on Commercial and Consumer Law (Oct. 17-18, 1980) (1982) 179, 180-185.

4. See n. 1, supra; also see C. Axworthy, "Controlling the Abuse of Small Claims Courts" (1976) 22 McGill L. J. 480; C. Axworthy, "A Small Claims Court for Nova Scotia - The Role of the Lawyer and the Judge" (1978) 4 Dal. L. J. 311; P. Sigurdson, "Small Claims Courts and Consumer Access to Justice" in Consumer Redress Mechanisms (1977) 1-136.

5. E.g. C. Axworthy, "Controlling the Abuse of the Small Claims Courts" (1976) 22 McGill L.J. 480. A lso see Zuker, "Quick Justice" (Nov. 1981) Can. Consumer 38.

6. See generally J.Ziegel, "The Future of Canadian Consumerism" (1973) 51 Can. Bar Rev. 191.

7. For a discussion of some of these features, see Belobaba, "The Resolution of Common Law Contract Doctrinal Problems Through Legislative and Administrative Interven. tion" in Studies in Contract Law (1980 Reiter and Swan eds.) 423. 
regulation in Canada. Of the 74 statutes respecting consumer protection and information in existence in 1978 in the ten provinces, 51 of them were passed after 1965. Sixty-five separate statutes were passed during the same period of time in connection with the licensing and regulation of businesses dealing with consumers. ${ }^{8}$

By the mid-1970's, every jurisdiction had also established a separate department or ministry to administer this legislation and, in most cases, to introduce consumer education programmes and to handle consumer complaints. In the case of British Columbia, for example, an average of seven to eight thousand formal complaints are handled annually and it is not unusual to see rebates or adjustment payments in the order of $\$ 700,000$ to $\$ 1,000,000$ annually as a result of the mediation activities of the Ministry's complaints officers. ${ }^{9}$ With respect to the regulation of the travel industry, the remedial approach has been followed in Ontario, Quebec and British Columbia to create a compensation fund for travellers who suffer losses through no fault of their own. ${ }^{10}$ The funds are created through levies on registered travel firms and aggrieved claimants look to these monies for their redress.

But it is my contention that extra-judicial alternatives for the handling of consumer claims (i.e. mediation officers and compensation funds) have been minor figures in the arena of consumer claims resolution. For the most part, where transactional rights and obligations have been affected by legislation since the mid-1960's, there has been an overwhelming reliance on the court system for the handling of disputes arising under those statutes."

The prevailing preference held by most governments for the adjudication of trade and consumer disputes by the courts in time has led to a reexamination of the adequacy of that forum to provide speedy and inexpensive redress. Initial studies suggested that few consumers ever appeared as plaintiffs in the courts and that many small claims courts functioned primarily as judicialized conduits for the recovery of business claims against unrepresented individual defendants. ${ }^{12}$ Commentators began to raise questions about gaps between rights in theory and redress in practice. The heads of criticism were well known by the early 1970's - accessibility, formality, cost and delay.

The criticism was not directed at the judges, clerks and others involved in the process - burdened down with archaic legislation, inadequate resources and frequently ignored in the setting of government priorities, they could only hope that better days were ahead. Sometimes their workload would be alleviated, however unwittingly, by a government

8. Responsible Regulation An Interim Report by the Economic Council of Canada (1979) Chapter 2, especially at 16-18.

9. B.C. Ministry of Consumer and Corporate Affairs, Annual Report for 1981 at 9 notes that "Ministry staff assisted consumers in recovering $\$ 714,654.39$ in rebates for goods and services that were unsatisfactory" and further "[t]here were 6,876 consumer com. plaints that required detailed inquiries and mediation."

10. Travel Agents Act, R.S.B.C. 1979, c. 409. The same legislation authorizes, interalia, the enforcement authorities to freeze the assets of travel agents and tour operators in the event of anticipated financial collapse to preserve the monies for claims by out-of-pocket customers; e.g., as described by the B.C. Ministry of Consumer and Corporate Affairs in a news release, "Collapse of Sunflight Vacations (B.C.) Ltd.", April 30, 1982.

11. This is certainly the case with provincial legislation affecting consumer product warranties, contract disclosure requirements and deceptive sales practices.

12. Supra n. 1. 
that would simply bar a certain class of claims from their jurisdiction. This happened in Alberta in 1975 when the far-ranging consumer redress provisions of that province's Unfair Trade Practices Act were restricted to the more expensive and inaccessible jurisdictions of the two senior trial courts in that province. ${ }^{13}$ The exclusion was not changed until 1980 when cases under the Act were placed within the jurisdiction of the pro-

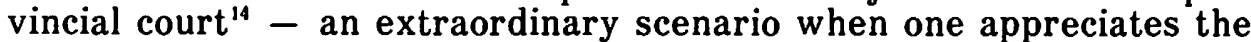
comprehensive invitation of trade practices legislation to self-help claims by consumer complainants. ${ }^{15}$

\section{DIVERSITY, UNIFORMITY AND CHANGE}

The Alberta Unfair Trade Practices Act illustrates the point that provincial legislation in just about any subject area, including consumer protection and small claims, is rarely based on a uniform model. ${ }^{16}$ You might wish to compare the 1979 Newfoundland ${ }^{17}$ and 1980 Nova Scotia ${ }^{18}$ statutes setting up small claims courts in each province. They are as different as night and day.

With few notable exceptions (such as property insurance and technical, non-contentious matters such as Interpretation Acts), ${ }^{19}$ the provinces do not have a record for achieving uniformity in legislation. In those instances in which uniformity has been achieved to any substantial degree (securities regulation comes to mind), the results can usually be traced to a special chemistry of one or two dominant provinces and a common resolve to thwart federal legislative inroads. ${ }^{20}$ In the commercial and consumer law spheres, one would be hard pressed to find compelling evidence of a practice of statutory harmonization.

Part of the "disharmony" ascribed to the provincial law making efforts may be explained by the tinkering that inevitably accompanies legislation which is based on an enactment introduced at an earlier date in another province. Some changes may also be tied to local conditions and the pride of legislative authorship. Let us remember that we are talking about elected governments, not Law Reform Commissions or uniformity commissioners. To some provincial ministers, uniformity is simply the result of accepting the drained and weakened product of political tradeoffs made in another province.

The remarks of Paul Weiler, the first Chairman of the British Columbia Labour Relations Board appear apt here. Using the example of labour law, he wrote some seven years ago: ${ }^{21}$

13. The Unfair Trade Practices Act, S.A. 1975, c.33, s.11, excluded proceedings under the Act from the jurisdiction of the Provincial Court.

14. The Unfair Trade Practices Amendment Act. 1980, S.A. 1980, c.49, s.4, added s.11.1 to the host Act.

15. E. Belobaba, "Unfair Trade Practices Legislation: Symbolism and Substance in Consumer Protection" (1977) 15 Osgoode Hall L.J. 327, 356; Trebilcock, A Study on Consumer Misleading and Unfair Trade Practices (1976) 8 (Vol. 2).

16. The lack of uniformity in consumer oriented legislation in Canada is discussed in greater depth at n. 3, supra, at 189-192.

17. The Small Claims Act, S.N. 1979, c.34.

18. Small Claims Court Act, S.N.S. 1980, c.16.

19. See Table I "Uniform Acts prepared, adopted, and presently recommended for enactment", Proceedings of the Uniform Law Conference, 1978, 356-357.

20. The provinces, led by Ontario, have responded resolutely and successfully to thwart federal initiatives in securities regulation forecast in Anisman, Proposals for a Securities Market Law in Canada (1979).

21. Excerpt, address by P.C. Weiler, May, 1975 (Mimeo). 
Experience has shown that provincial jurisdiction in Labour Law allows great scope for diversity and serious innovation. The source of strength in Canadian Labour Law policy, as it has and will emerge in the 1970 's, is the diversity which comes from provincial authority. Each legislature responds to different characteristics of its own environment. If a statutory experiment proves successful, it can be and is emulated elsewhere in the country. If it proves a mistake, it can quickly liquidate it without widespread damage.

There is a case to be made, then, for strength and innovation in diversity. Uniformity for its own sake, whether it be in consumer remedies, the enforcement of judgments or the legislative design of courts, is not an end in itself.

Too often uniformity stifles creativity and delays the introduction of useful law reform adapted to local conditions and needs. If we were to submit to the yoke of complete statutory harmonization, it is quite certain that we would still be waiting for the introduction and the chance to assess the operation of a number of important initiatives taken in Canada in the past decade, including the barring of lawyers in the Quebec system, ${ }^{22}$ the court referees in British Columbia, ${ }^{23}$ the opportunities for informal adjudication by consent in Saskatchewan ${ }^{24}$ and the new statute in Nova Scotia ${ }^{25}$ which has been in operation for just over a year. Unlike most statutes, the Nova Scotia product confidently carries an introductory section announcing that its "intent and purpose ... [is] to constitute a court" in which claims are "adjudicated informally and inexpensively but in accordance with established principles of law and natural justice". ${ }^{26}$

In the same statute, business plaintiffs are not allowed to sue on the basis of assigned debts, ${ }^{27}$ an obvious response to the bad debt merchants who have dominated the dockets in some small claim courts. The same provision gives the Attorney-General the power by regulation to prescribe the "days and hours during which a corporate person, its agent or solicitor, shall not appear before the court as a plaintiff" - a power, according to the Act, "to better effect the intent and purpose of this Act and to facilitate the litigation of claims and defences of natural persons".

The other recent development that we might note is the three year pilot project in Metropolitan Toronto involving four of that area's existing small claims courts. According to the legislation setting up the experiment, its purpose is to encourage "the development of simplified procedures and methods of making civil remedies more accessible and reducing delays". ${ }^{28}$ As described in a recent article by Judge Zuker, ${ }^{29}$ the project is attempting to reduce litigation costs by simplifying four aspects of civil procedure: pleadings, motions, discovery and trials. One page claim forms are encouraged, pre-trial motions are generally not per-

22. Quebec Code of Civil Procedure, 1965, Arts. 955, 956, 985. The prohibition of lawyers from the Provincial Court, Small Claims Division, was unsuccessfully challenged on constitutional and civil rights grounds in Nissan A utomobile Co. (Canada) Ltd. v. Pelletier (1978) 97 D.L.R. (3d) 277 (C.A.); affg (1976) 77 D.L.R. (3d) 646 (S.C.).

23. The authority to appoint court referees, originally granted by the Provincial Court Act. R.S.B.C. 1979, c.341, s.6(3) (duties and responsibilities in ss.33-34), was repealed by S.B.C., 1981, c.26, s.3.

24. The Small Claims Enforcement Act, R.S.S. 1978, c.S-51, s.33.

25. Small Claims Court Act, S.N.S., 1980, c.16.

26. Id., s.2.

27. Id. s.5.

28. The Provincial Court (Civil Division) Project Act, 1979, S.0. 1979, c.67, s.2. The rules of the Court are found in Ont. Reg. 470/80.

29. Zuker, supra, n. 5. 
mitted and discoveries are discouraged. Pre-trial hearings may be convened at the option of the presiding judge to assist settlements or to improve the preparation for trials particularly where a party may be unrepresented.$^{30}$ Given the trends in a number of other jurisdictions, ${ }^{31}$ it is surprising to see that a counsel fee of up to $\$ 300$ may be awarded along with a further $\$ 30$ for the preparation and filing of pleadings. ${ }^{32}$ By way of contrast, the British Columbia legislation forbids the charging of counsel fees of any kind against either party ${ }^{33}$ and the Quebec statute prohibits representation by counsel in the small claims court..$^{34}$

These most recent provincial initiatives illustrate the capacity for local change and experimentation in a federal system. As a matter of general principle, that is a very persuasive position to support. However, it is less obvious whether the cumulative, cross-country result of these many and varied provincial changes is as satisfactory as it might be. After ten years of often very active law reform, what has been the net result for Canadians? Might this not be an appropriate time, some ten years after the initial reforms in Manitoba ${ }^{35}$ and Quebec, ${ }^{36}$ to take stock of our present situation?

Have we in the pursuit of separate provincial models created a patchwork of systems common in name only or have we carefully learned from each other's successes and failures in an ongoing, coordinated effort to fashion workable, improved standards for small claims adjudication systems? Over the past 10 years, have we managed to settle on the size of claims and the types of cases that can be most appropriately handled in the simpler, more informal and less expensive system of courts? Do we have a better, more informed idea of what small claims judges should do in resolving disputes? In short, what have we learned from each other? Surely the considerable pace of legislative change in the powers, procedures and makeup of these courts by the majority of provinces has not taken place in a policy vacuum.

Without suggesting that fresh thinking should be stymied or sidetracked, I have come to the conclusion that the present hodgepodge of small claims legislation is unsatisfactory and moreover, could become the status quo since governments now have other priorities in the face of serious economic difficulties. In more buoyant times, this erratic picture might have been portrayed more sympathetically as the price of change that would in time, settle down and smooth out to yield a more effective and comparable standard of speedy, inexpensive justice across the country. But we might not be so fortunate this time. While a decade of rather energetic reform has produced some truly interesting and valuable steps towards that goal, there has been a troubling failure to come to grips with basic standards of jurisdiction, evidence and costs. A citizen's accessibility to effective civil justice ought not to rise or fall on the accident of residence. Yet, we have such a patchwork of small claims systems in

30. Ont. Reg. $470 / 80$, s.48.

31. Summarized in Sigurdson, supra n. 4 at 55.

32. Ont. Reg. 470/80, Tariff of Costs.

33. Small Claim Act. R.S.B.C. 1979, c.387, s.56.

34. Quebec Code of Civil Procedure, 1965, Arts. 955, 956, 985.

35. Helpfully described in Sigurdson, supra n. 4 at 9-10.

36. Id. at 11-12. 
Canada that we must wonder if we have really made an effort to learn from each other's attempts in designing courts for the resolution of disputes under $\$ 5,000$.

\section{SOME SPECIFICS}

Let us consider some specific items beginning with the monetary jurisdiction of small claims courts. We would probably all agree that the primary function of the small claims system is to provide an inexpensive, efficient and accessible forum for the adjudication of disputes involving relatively small amounts of money. But as Judge Zuker of Ontario recently noted, "a $\$ 5,000$ case in 1982 can be considered a relatively 'small' case". ${ }^{37}$ Across this country there are extraordinary disparities in the monetary jurisdiction of small claims courts, ${ }^{38}$ from $\$ 250$ in New Brunswick, ${ }^{39} \$ 500$ for individual plaintiffs in Saskatchewan, ${ }^{40} \$ 1,000$ in Alberta $^{41}$ and Newfoundland, ${ }^{42} \$ 2000$ in B.C. ${ }^{43}$ and Nova Scotia ${ }^{44}$ to $\$ 3,000$ in Ontario ${ }^{45}$ In some cases, the failure to catch up to economic realities may be traced to legislative ignorance or a lack of political interest. However, in many of the examples cited, the monetary ceilings were fixed as recently as a year or two ago and it is difficult to fathom the reasoning for setting such low amounts. One of the results must surely be to create a barrier to affordable and accessible adjudication.

The small claims monetary ceilings have not been adjusted upwards in line with the more regularly paced increases in the monetary jurisdiction of the district or county courts. Further comment on this relationship would be welcomed since these comments are based only on preliminary inquiries. But first impressions suggest that the monetary jurisdiction of the small claims courts in Canada in these inflationary times, far from expanding, is actually contracting, in constant dollar terms. Indeed, in some provinces where the ceiling is $\$ 500$ or less, we would have to conclude that there is a preference to place most disputes of even modest amounts into the district or county courts. Why would this be done?

What accounts for the puzzling differences in the type of cases that can be heard by small claims courts in Canada? Most of them have jurisdiction in respect of matters in contact or in tort but some are expressly barred from hearing cases involving the recovery of personal property ${ }^{46}$ and, as we have seen, sometimes from matters arising from rights created in consumer protection statutes. ${ }^{47}$ Are the many differences in jurisdictional coverage to be dismissed as historical quirks or local anachronisms of little substantive effect? Or are they further evidence of a long standing resistance by Attorneys-General to broaden the work base of the court? Why does this attitude prevail?

37. Zuker, supra n. 5 at 40.

38. Confirmed in the 1977 survey by Sigurdson, supra $\mathrm{n} .4$ at 29-30.

39. Cited by Sigurdson, supra n. 4 at 12, but not ascertainable in the County Court Act. R.S.N.B. 1973, c.C.30.

40. Small Claims Enforcement Act, R.S.S. 1978, c.S.51, s.3.

41. Provincial Court Act, R.S.A. 1980, c.P-20, s.36.

42. The Small Claims Act, S.N. 1979, c.34, s.3.

43. Small Claim Act, R.S.B.C. 1979, c.387, s.2.

44. Small Claims Court Act, S.N.S. 1980, c.16, s.9.

45. At least in cases governed by The Provincial Court (Civil Division) Project Act, 1979, S.0. 1979, c.67, s.6.

46. E.g., barred in Alberta but permitted in B.C., Sask., and Nova Scotia.

47. See the text accompanying n. 13, supra. 
Or consider continued failure to provide even minimum pre-trial counselling to unadvised consumer litigants. Virtually every interview with a small claims judge points to the ill-prepared party as a chief contributor to the delays that appear to bedevil the system. Advice on the pre-trial preparation of small claims litigation requires paralegal resources to help the unrepresented litigant. Sometimes community law offices can be of some help, but so far as I know, small claims cases are not eligible for legal aid and any proposals for duty counsel have been rejected on budgetary grounds. Yet, will our many efforts to design the court system to cut down on paperwork and to simplify procedures yield meaningful results if some form of legal advice on case preparation is not available? Interviews suggest that the dilemma is well recognized but that the answers are elusive and resources are lacking.

Meanwhile, the reason most frequently given for delays in most of the present systems is that the parties are not prepared to proceed with their cases when their time for trial comes up. The results are all the more exasperating for everyone involved when one remembers that they might have waited three to five months to get that far. In commenting on the Toronto project, Judge Zuker offered the hope that it might be possible to work out a 100 day time frame for most cases by simplifying paper work, cutting down on motions and the like ${ }^{48}$ Certainly, in jurisdictions where delays of 4 to 6 months are not uncommon, 100 days sounds like speedy justice. But is it really very timely to tell a claimant in January that if all goes well, his case will be heard in April?

Further, it should not be forgotten, whether we are working with the 4 month norm in British Columbia or the 3 month turnaround time in Toronto, that motions and other procedural moves by the unprepared or the unscrupulous will easily double the time frame. This is a sizeable disincentive for anyone contemplating an action and a fact of life knowingly exploited by devious litigants who will defend an action without merit and, in the process, bargain for a settlement that does little to inspire confidence in the judicial system.

Every available research project on the issue confirms the need to think more imaginatively about the simplification of procedures, some para-legal help in preparing a case, optional mediation procedures and a relaxation of the rules of evidence. As it is unlikely that more judges and courtrooms are going to be made available in these times of restraint, what can we learn from the rather helter-skelter developments in Canada that will give us faster justice for the same price? Is it an impossible challenge?

In taking stock of Canadian developments over the past 10 years, let us not overlook the human dimension of adjudicating small claims disputes. The job of small claims judges usually involves an unrelenting caseload, a fair bit of repetition in terms of the character of the cases and considerable stress in straightening out litigants who may be mismatched or unprepared or both. In the many efforts over the past ten years to redesign the small claims court system, has sufficient notice been paid to the personal demands made of the judges and the price to be paid for judicial fatigue or burnout? Is the present system fair to them or to the

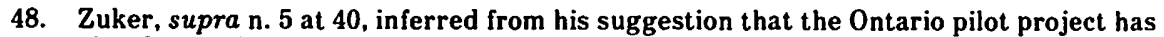
aimed at reducing unreasonable delays. In this context "[w]e may have to develop specific time frames for individual cases; for example, impose a schedule of 100 days for a case to be disposed of from the time a defence is filed." 
litigants over the longer run? At what point do the benefits and advantages of experience start to slip? Are there other forms of tenure, or work assignment or professional diversification that might be explored in this connection? If these questions are not pursued, then the small claims judiciary stands in splendid isolation from the available evidence on work stress, mental fatigue and career motivation. Social workers, complaints officers and case mediators have figured prominently in these workplace studies. Is there comparable data available on the effects of the present systems on small claims adjudicators? Have we given appropriate weight to these important personnel considerations in our efforts at law reform?

\section{TAKING STOCK - A TIME TO LEARN}

The principal goals of law reform in small claims resolution were identified in 1979 in a report entitled "Simple Justice" published by the $\mathrm{Na}$ tional Consumer Council in the United Kingdom. ${ }^{49}$ The criteria were simply listed as accessibility, simplicity, informality, cost, speed, effectiveness, and fairness.

If we accept the widely held view that restraints in government expenditures will be a fact of life for some time, then the challenge that presents itself to this conference is quite obvious. Our collective task, it is respectfully suggested, is to evaluate the present system in Canada for the adjudication and resolution of small claims disputes. The assessment criteria used by the National Consumer Council are admirably suited to the task.

Tight money and shifting spending priorities will put in jeopardy any suggestions for change that involve significant expenditures without compensating revenues or equivalent savings elsewhere in the small claims system. A pproval for the funding of pilot projects, new facilities, and the appointment of more judges will not be forthcoming. Nor may the possibility of uninformed pressures to downgrade or reduce local court services by cutting back on support help be discounted.

But restraint and the curtailment of important inputs to the system need not be synonymous with inaction or stagnation. The challenge is two-fold. First, we require a rigorous, disciplined assessment of the present scene in Canada. How do we match up to the evaluation criteria just mentioned? This paper has attempted to draw our attention to the hills and valleys of our experience, particularly as it has evolved over the past decade.

Our findings in each jurisdiction would help to identify the most costeffective measures, consistent with fairness and justice, that are likely to attain results explicitly recognized in the assessment criteria. At the end of the day, we may predict the exercise will focus on steps towards realistic jurisdiction, simplified procedures and fewer delays. Labour intensive approaches to pre-trial counselling may be difficult to promote in the face of spending restraints, even when their net savings can be identified. However, the potential for Telidon-type instruction should not be overlooked in this connection, particularly when the hardware itself is being provided for a wide variety of commercial and public purposes at highly subsidized prices by the federal government.

49. National Consumer Council, Simple Justice (1979), discussed in the context of 1981 English rule changes in Thomas, "Small Claims - The New Arrangements" (A pril 1981) New L.J. 429.431. 
While the golden days of pilot projects in mediation may be waning, the present experience in several places, including Ontario ${ }^{50}$ and British Columbia, ${ }^{51}$ ought to be analyzed as soon as possible, for their common objective is to settle disputes quickly, to the satisfaction of the parties, at minimum cost. If their results are encouraging, then far from storing the lessons away for more buoyant times, policymakers ought to think carefully about the appropriate mix of resources and procedures for the resolution of small claims disputes. Formal courts have no monopoly on expertise or wisdom in these matters.

\section{REFLECTIONS AND CONCLUSIONS}

We have come through a decade of considerable change, much of it quite uneven, across the country. A number of significant changes have been made in several provinces to provide a small claims system that will handle disputes in a more informal, expenditious and less costly manner. The advent of county clerks in Manitoba, informal voluntary adjudication in Saskatchewan, the pilot project in Toronto, the significant reforms in Quebec, the appointment of adjudicators under a new statute in Nova Scotia, the efforts to use referees in British Columbia, the linkups with debtor counselling and debt repayment programs, all of these developments attest to a resilient and serious interest in a good number of the provinces in fashioning appropriate mechanisms for the disposition of small claims disputes.

There have also been important developments in provincial legislation and government programs to improve the chance for satisfactory redress to consumers through mediation services for consumer-merchant disputes and compensation funds for prepaid consumer contracts. In six provinces, ${ }^{52}$ legislative authority in trade practices statutes permits enforcement officers to obtain redress for consumers under compliance agreements negotiated with businesses alleged to be operating in a deceptive or unconscionable manner in the marketplace. Under these assurances of voluntary compliance, the suspect activities are stopped and, quite often, redress for aggrieved consumers figures in the undertaking made by the supplier. Over one hundred of these compliance agreements affecting thousands of transactions have been signed with enforcement authorities, principally in Alberta and British Columbia, but also in Quebec and Ontario. ${ }^{53}$

When you stand back and look at the total scene, you might say it looks typically Canadian - some legislative arm-waving, a fairly steady number of pilot projects at any given moment and an uneven commitment to separate provincial initiatives. There is little doubt that some progress has been made in striving for the goals identified by the U.K. National Consumer Council. But has there been sufficient progress over the past decade? Are small claims courts really that much more accessible to the lay public than they were ten years ago? Have long identified problems of delay and formality been overcome? Does a citizen's readiness to use the

50. Windsor-Essex Mediation Centre, Windsor, Ontario.

51. Details available from Ms. Kathleen Morrison, Court Referee, Provincial Court of British Columbia, 700 W. Georgia Street. Vancouver.

52. Ontario, Alberta, B.C., Quebec, Prince Edward Island and Newfoundland.

53. W. Neilson, "Administrative Remedies: The Canadian Experience with Assurances of Voluntary Compliance in Provincial Trade Practices Legislation" (1981) 19 Osgoode Hall L.J. 153, 167-173. 
small debts system depend more on the accident of his or her province of residence than on the merits of their case? Do we really have a nationwide perspective on the operation and effectiveness of the most utilized civil court jurisdiction in Canada? Our field experience is rich and the results are available to a national study task force which would need minimal resources. The challenge is there and I commend the proposal to this conference. 